\title{
GEOLOGICAL MODEL OF MAUDDUD FORMATION IN BADRA OILFIELD
}

\author{
${ }^{1}$ Mena Jamal Faisal and ${ }^{2}$ Thamer A. Mahdi \\ ${ }^{1,2}$ Department of Geology, College of Science, University of Baghdad, Baghdad, Iraq \\ *Email: Mena.gamal2016@yahoo.com \\ Received: 3 September 2019; accepted: 9 October 2019
}

\begin{abstract}
A 2D geological model for Mauddud Formation in the Badra oil field is built using Rockworks 16 software. Mauddud Formation produces oil from limestone units; it represents the main reservoir in the Badra oil field. Six wells (BD-1, BD-2, BD-4, BD-5, P-15, and P19) are selected to build facies and petrophysical (Porosity and Water saturation) models. Wells data are taken from the core and cutting samples and studied through the microscopic. The petrophysical data (effective porosity and water saturation) are derived from computer processes interpretation results that are calculated by using Interactive Petrophysics software. The $2 D$ models are built to illustrate the vertical and horizontal distribution of petrophysical properties between wells of the Badra oil field. The facies model of Mauddud Formation shows the dominance of open marine facies in the upper and middle parts of the formation, whereas mid-ramp facies occupies the lower part. The shoal facies represents approximately continuous units among wells of study. According to the results of petrophysical models, the effective porosity increases towards the wells which occupy a higher structural depth while the water saturation increases toward the wells which occupy the lower structural depths. The hydrocarbons are mainly accumulated in the high structure parts of the Badra field within Mauddud Formation.
\end{abstract}

Keywords: Badra oil field; Geological Modelling; Mauddud Formation; Rockworks16

\section{INTRODUCTION}

Mauddud Formation includes important carbonate reservoirs in the Arabian plate region (Cross et al., 2010). The formation has regional distribution and thickness all over the Arabian plate (Sadooni and Al-Sharhan, 2003). In central Iraq, Mauddud Formation produces oil in Badra oil field from limestone units. Other equivalent formations in neighboring countries also produce from similar units, although somewhat varied carbonate microfacies. There are many ways to create reservoir models and the process followed will illustrate the distribution of facies, 
porosity, and water saturation. Rockware 16 was chosen to model data in this research because it is capable of analyzing and visualizing borehole point and interval data. Geological modeling is an applied science of creating a computerized representation of portions of earth's crust, especially the oil and gas field. In the oil and gas industry, realistic geologic models are required as input to reservoir simulator programs, which predict the behavior of rocks under various hydrocarbon recovery scenarios (Turner and Gable, 2008). The aim of this paper is to build 2D geological models for six wells of Mauddud Formation in the Badra oil field. The 2D geological models include the facies and the petrophysical (effective porosity and water saturation) models.

\section{GEOLOGICAL AND TECTONIC SETTING OF STUDY AREA}

Badra oil field is located in central Iraq, near the Iraqi-Iranian border (Fig.1). Tectonically, it lies within two zones, Mesopotamian Zone (Tigirs Subzone) and Foothill Zone (HimreenMakhul Subzone) (Jassim and Goff, 2006). Six wells are selected in this study that is distributed along with the anticline structure of the Badra oil field (Fig.2). The main lithology of Mauddud Formation includes limestone units which can be chalky, stylolitic, detrital, and dolomitic. The rocks were dated as an Albian age (Bellen, 1959). The depositional setting of Mauddud Formation in the Arabian plate is represented by a ramp fringed shoals and rudistbiostromes (Cross et al., 2010). The area covers Badra oil field, which is located in Wasit Governorate, approximately $160 \mathrm{~km}$ south-east Baghdad and extends across the border with Iran (Fig. 1). The selected wells are listed in Table (1).

Table 1: The geographic coordinates of studied wells in Badra oilfield (Final geological reports)

\begin{tabular}{|c|c|c|c|c|}
\hline Well name & Eastern & Northern & Top & Bottom \\
\hline BD-1 & 3659008.154 & 597233.479 & 4524,5 & 4903 \\
\hline BD-2 & 3654718.086 & 604708.616 & 4351,6 & 4582,6 \\
\hline BD-4 & 3658465.189 & 601851.302 & 4486,6 & 4760 \\
\hline BD-5 & 3657739.128 & 599554.854 & 4469,8 & 4750 \\
\hline P-15 & 3654459.231 & 602826.588 & 4488,4 & 4763 \\
\hline P-19 & 3660150.911 & 597813.044 & 4572,1 & 4840 \\
\hline
\end{tabular}




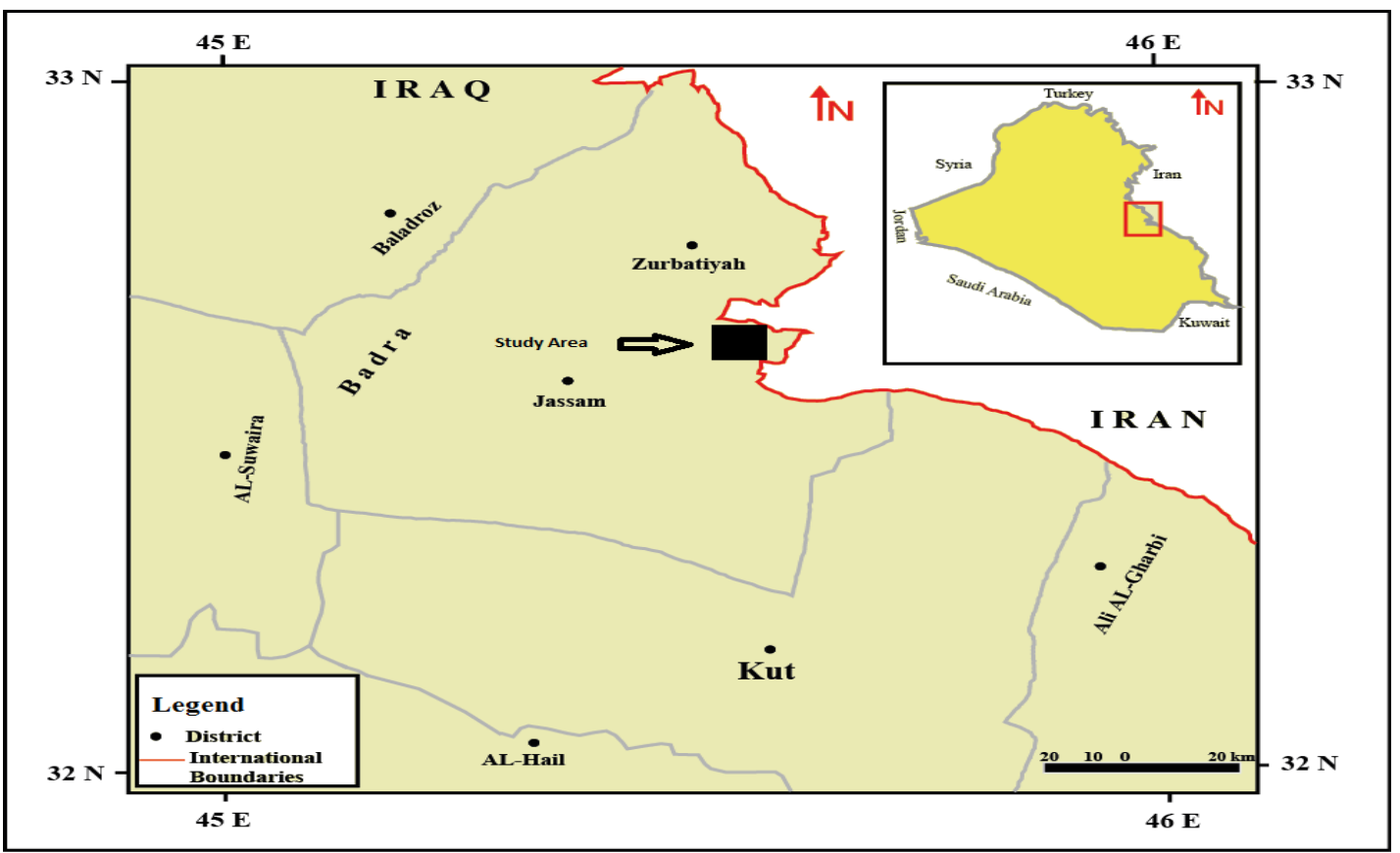

Fig. 1: Location map of the study area

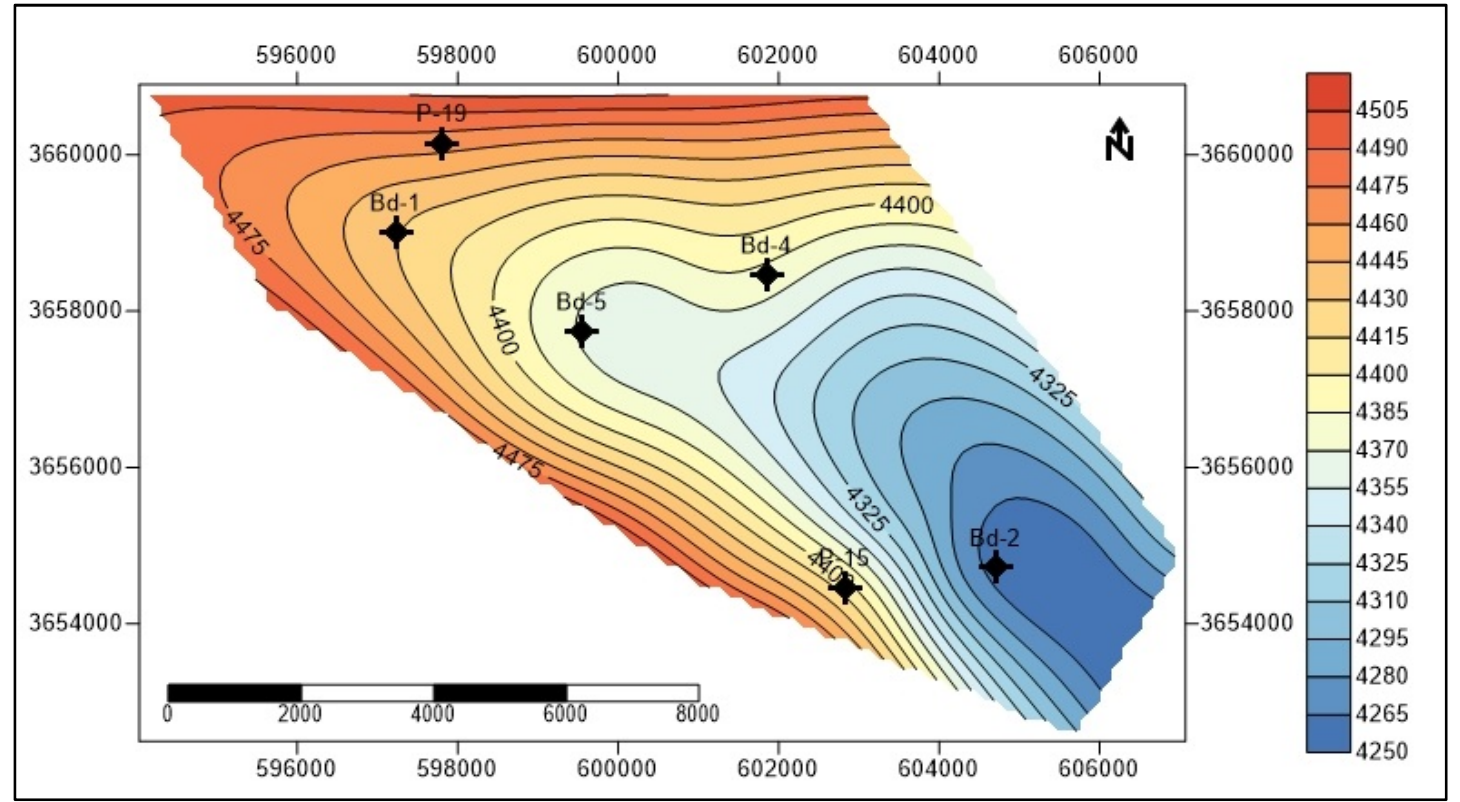

Fig. 2: Structure map at top of Mauddud Formation

\section{METHODOLOGY}

Data preparation is the base of the geological model. The data preparation for this $2 \mathrm{D}$ geological model is:

1. Location data: Borehole location information including borehole ID and coordinates (Easting/Northing coordinate) and well elevation. 
2. Interval data (I-Data): Data sheet is used to list depth intervals and one or more columns of numeric data to be plotted. For reading irregularly spaced, classification data in an existing I-data column and resample them to a specified depth interval, recording the resample values in a user selected I-data column. The depth of each facies association and its thickness, color and type are entered by the chosen I-data option.

3. Point data (P-Data): These data include single depth and multiple columns of measurements. These values belong to effective porosity (PHE) and water saturation ( $\mathrm{Sw})$ values.

\section{PROPERTY MODELING}

Property modeling shows the distribution of facies and petrophysical properties between wells in a way that maintains the reservoir homogeneity and conforms to the wells' data (Schlumberger, 2010). The facies and petrophysical models in this study have two-dimension for Mauddud Formation and built through two NW-SE correlation sections. The first section (A1) passes through wells BD-1, BD-5, and P-15, the second (A2) includes the wells BD-2, BD-4, P-19 (Fig. 3).

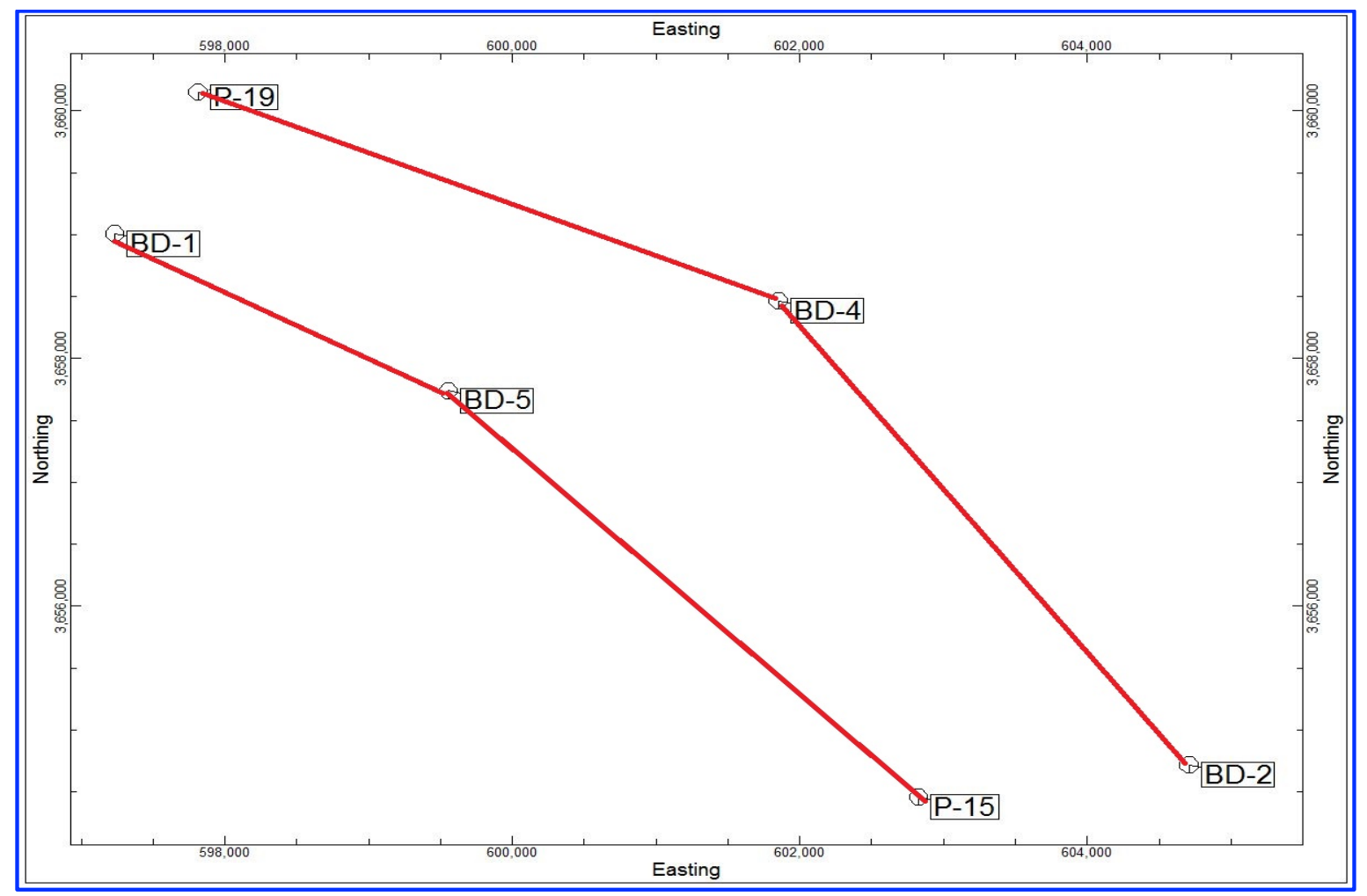

Fig. 3: Location map of the studied wells and the direction of correlation sections used in reservoir modelling 


\section{FACIES MODELING}

The facies modeling shows the geometries of facies and possible relationships within a stratigraphic sequence. It represents an important component of geostatistical reservoir characterization and facilitates construction of superior reservoir models (Schlumberger, 2010). Facies interpretation in terms of depositional environment is based on the microfacies study. For this purpose, the classification of carbonate rocks by Dunham (1962) is used to describe and interpret the microfacies of Mauddud Formation. The previous studies in Iraq suggested the ramp model as a depositional setting for Mauddud Formation.

The same assumption is also documented in equivalent formation in neighboring countries as in Kuwait (Cross et al., 2010). Therefore, the ramp model is applied in this study. Five facies association were distinguished in Mauddud Formation. They include an outer ramp, mid ramp, shoal, open marine and restricted marine (Pl.1).

In this study, the 2D facies model of Mauddud Formation is constructed across two different sections through the Badra oil field (Fig.3). In both sections (A1 and A2), the facies model of Mauddud Formation shows the dominance of open marine facies in the upper and middle parts of the formation, whereas mid-ramp facies occupy the lower part. The shoal facies represent approximately continuous units among wells of study at different depths or show pinch out the pattern (Figs. 4 and 5).

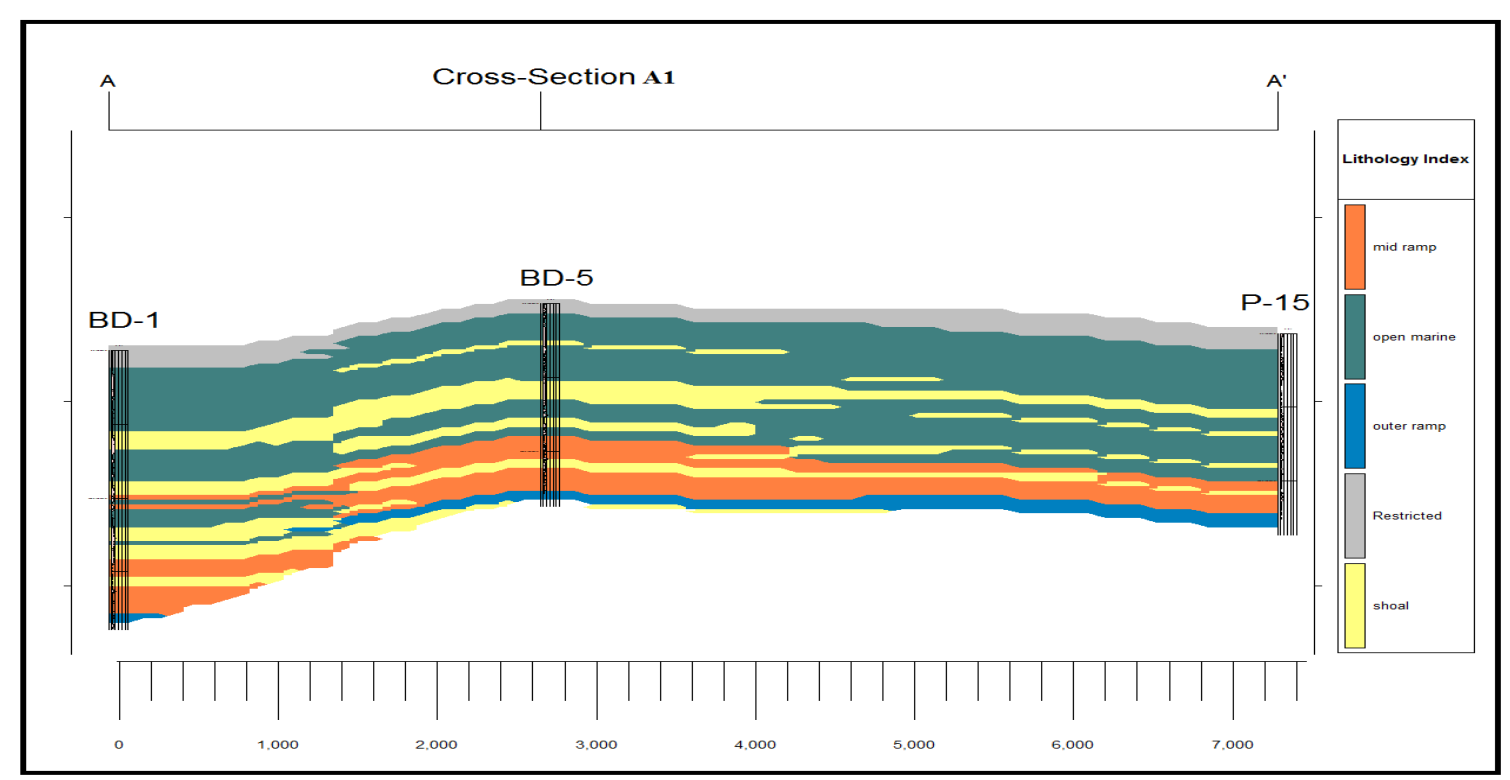

Fig. 4: Facies model of Mauddud Formation at section A1 


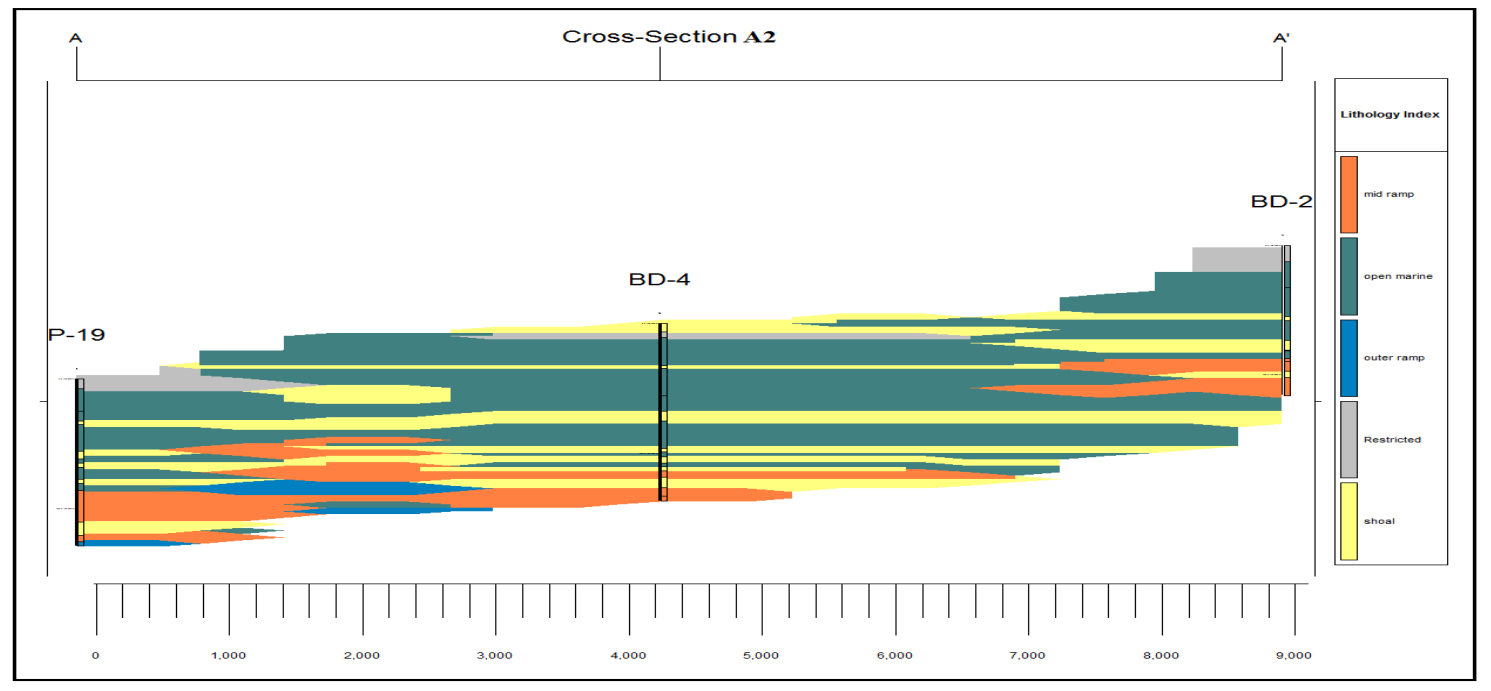

Fig. 5: Facies model of Mauddud Formation at section A2

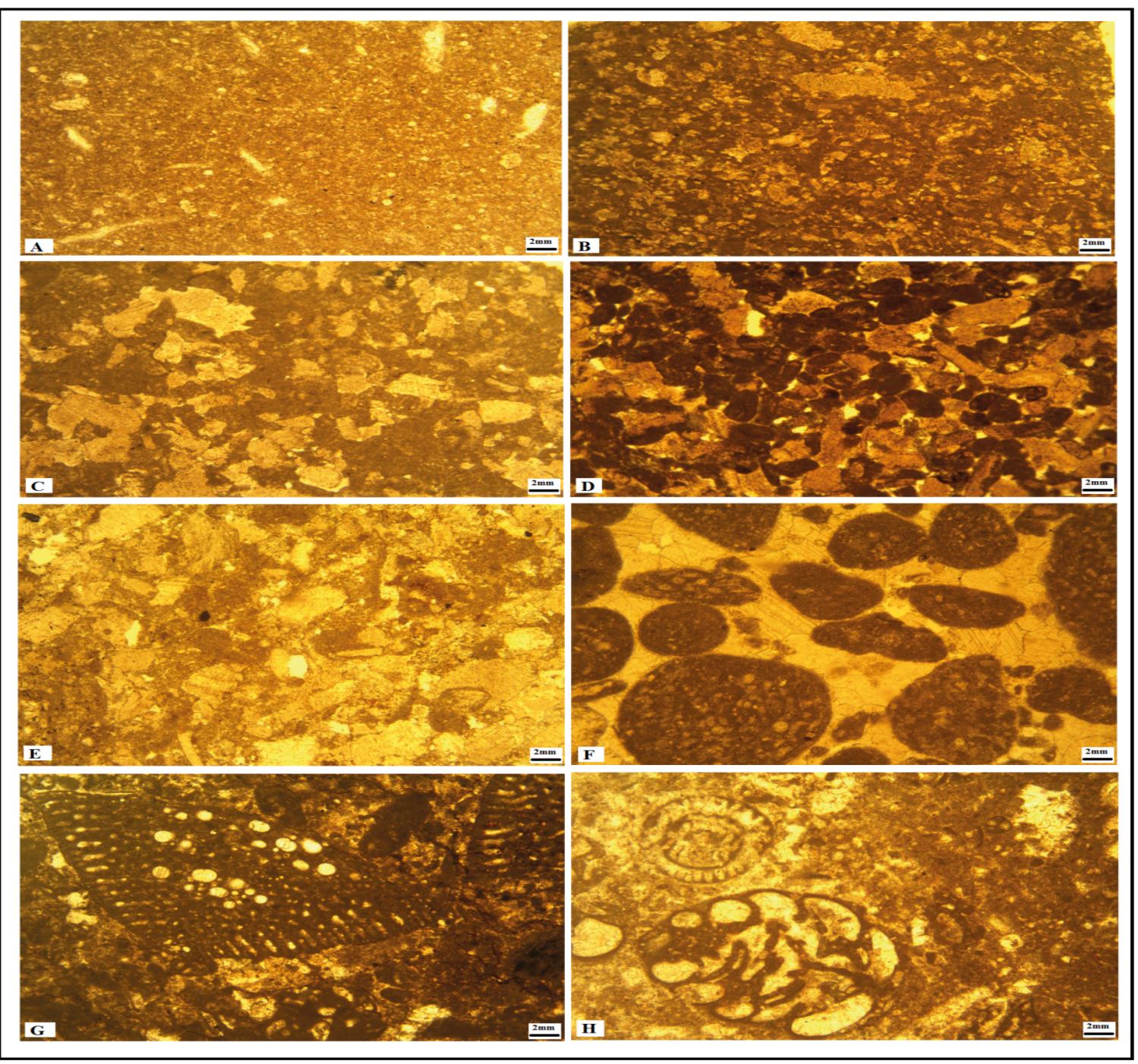

Plate-1: Microfacies of Mauddud Formation in Badra oil field 


\section{PETROPHYSICAL MODELING}

The main petrophysical variables needed for petrophysical modeling are porosity, water saturation, and permeability (Cannon, 2018). Petrophysical modeling is the process of assigning the values of these variables for each facies and reservoir layer (Pyrcz and Deutsch, 2014). The values of effective porosity and water saturation of Mauddud Formation are imported as P-data into Rockworks software for modeling step.

The petrophysical data are derived from computer processes interpretation (CPI) results that are calculated by using Interactive Petrophysics (IP) software (Fig. 6).

\section{Porosity Model}

The aim of the porosity model is to visualize the distribution of porosity within the borehole as realistically as possible preserving the heterogeneity of the geological subsurface (Bellorini et al., 2003).In the current study, the effective porosity model is built depending on the porosity $\operatorname{logs}$ (density, neutron, and sonic logs) that are calculated by using IP software. The effective porosity is used in petrophysical modeling because it provides accurate volumetric results (Cannon, 2018).

Figures $(7 \& 8)$ show the effective porosity model of Mauddud Formation, along two sections. In section A1, the effective porosity increases towards well BD-5, which occupies a higher structural depth (Fig.7). The values are significantly reduced toward the deepest structural depth in well P-19 (Fig. 8). The effective porosity increases in shoal and open marine facies are distinguished by grain-supported texture, which makes them have good reservoir properties.

\section{Water Saturation Model}

The values of water saturation are imported into Rockworks software as P-data. Figures (9) and (10) show the water saturation model of Mauddud Formation at two sections. Section A1shows the increase of water saturation towards well BD-1at the bottom of Mauddud Formation. The well BD-1 occupies the deepest structural depth along section A1 (Fig.9). In a similar trend at section A2, the well P-19 shows the highest water saturation values, while the values increase upward of Badra structure (Fig.10) 


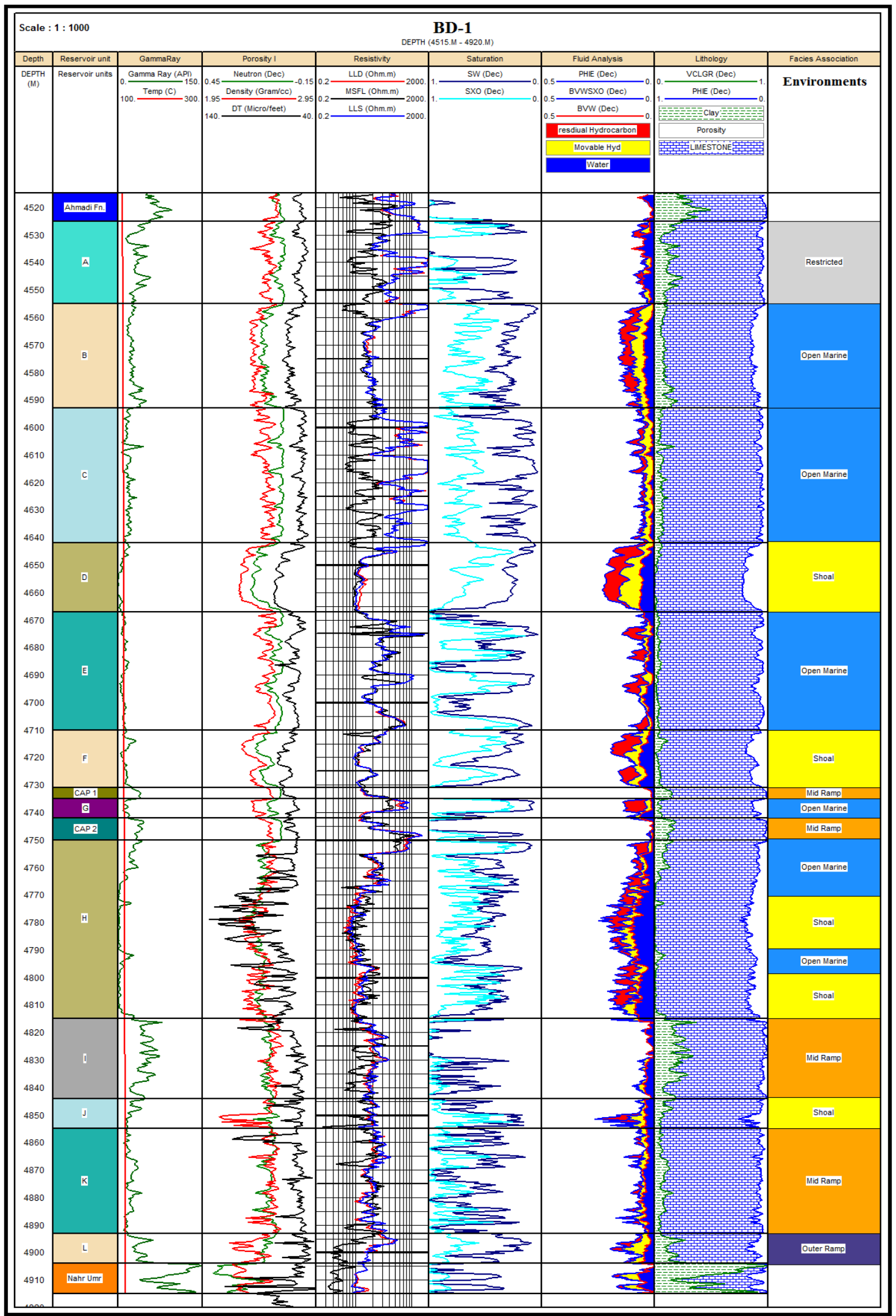

Fig. 6: Computer Processes Interpretation (CPI) of well BD-1 


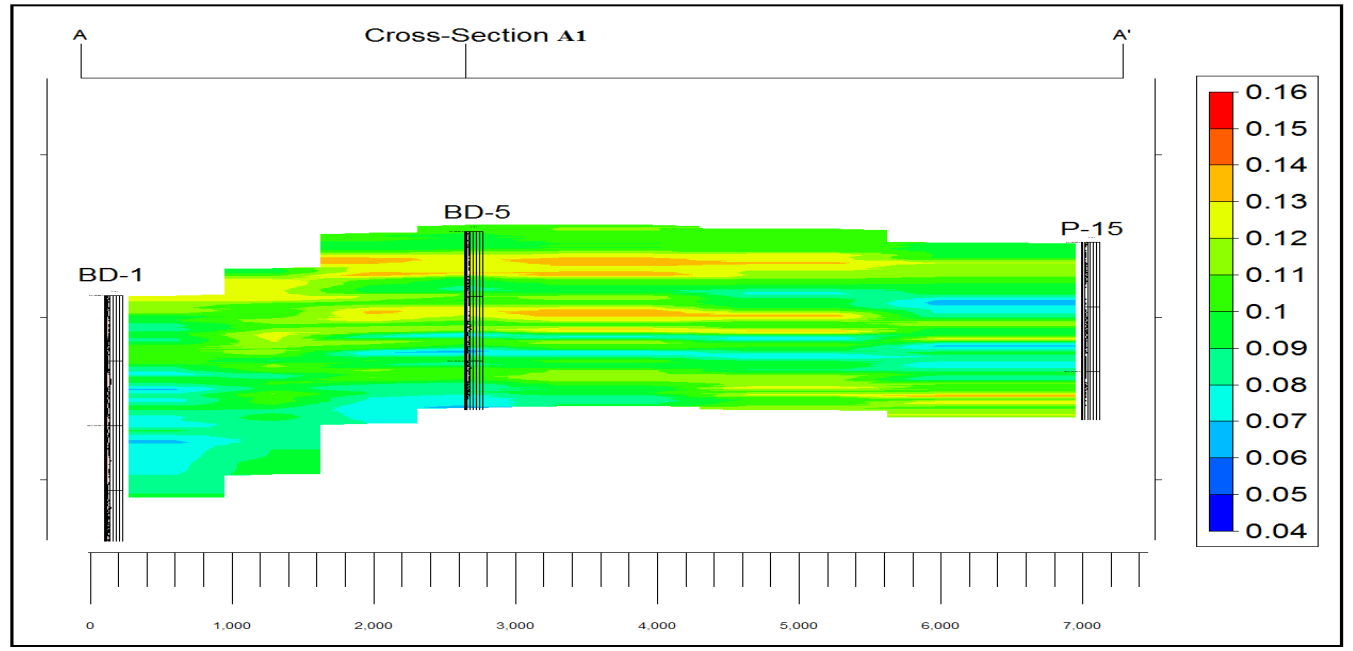

Fig. 7: Effective porosity model of Mauddud Formation at section A1

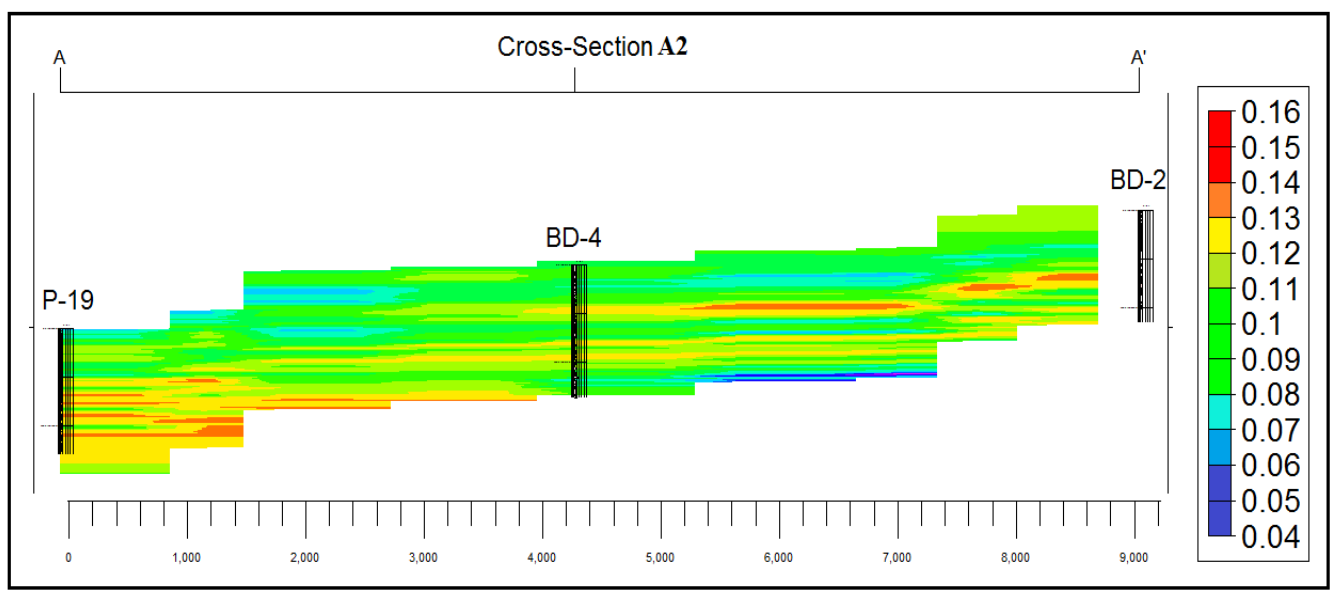

Fig. 8: Effective porosity model of Mauddud Formation at section A2

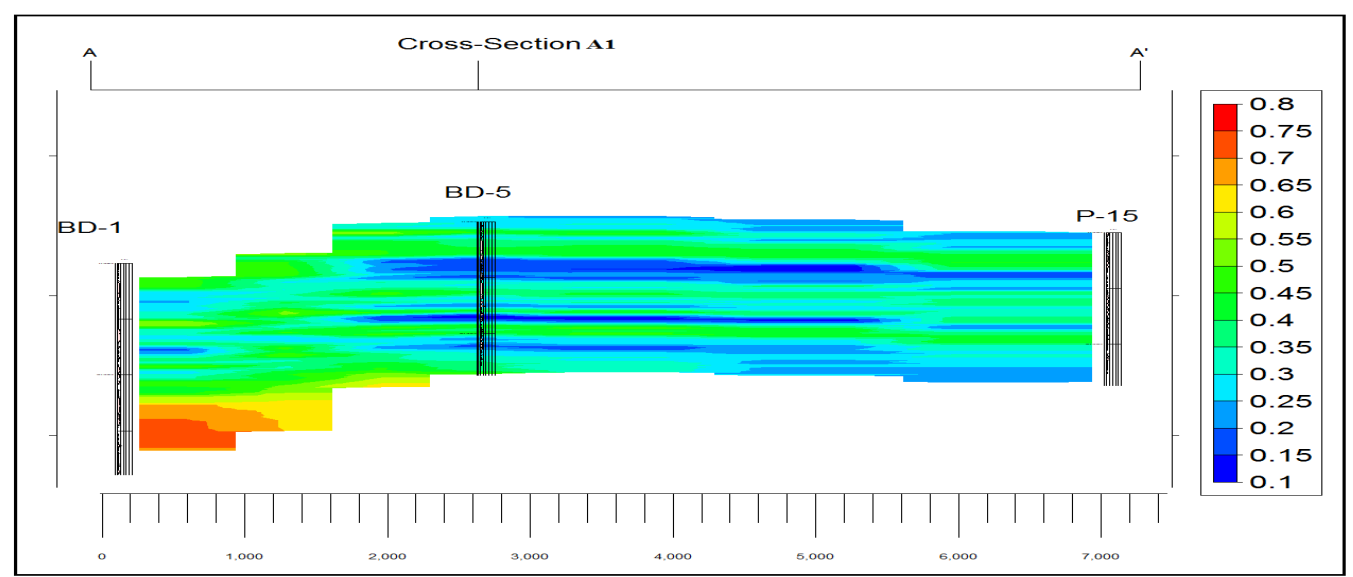

Fig. 9: Water saturation model of Mauddud Formation at section A1 


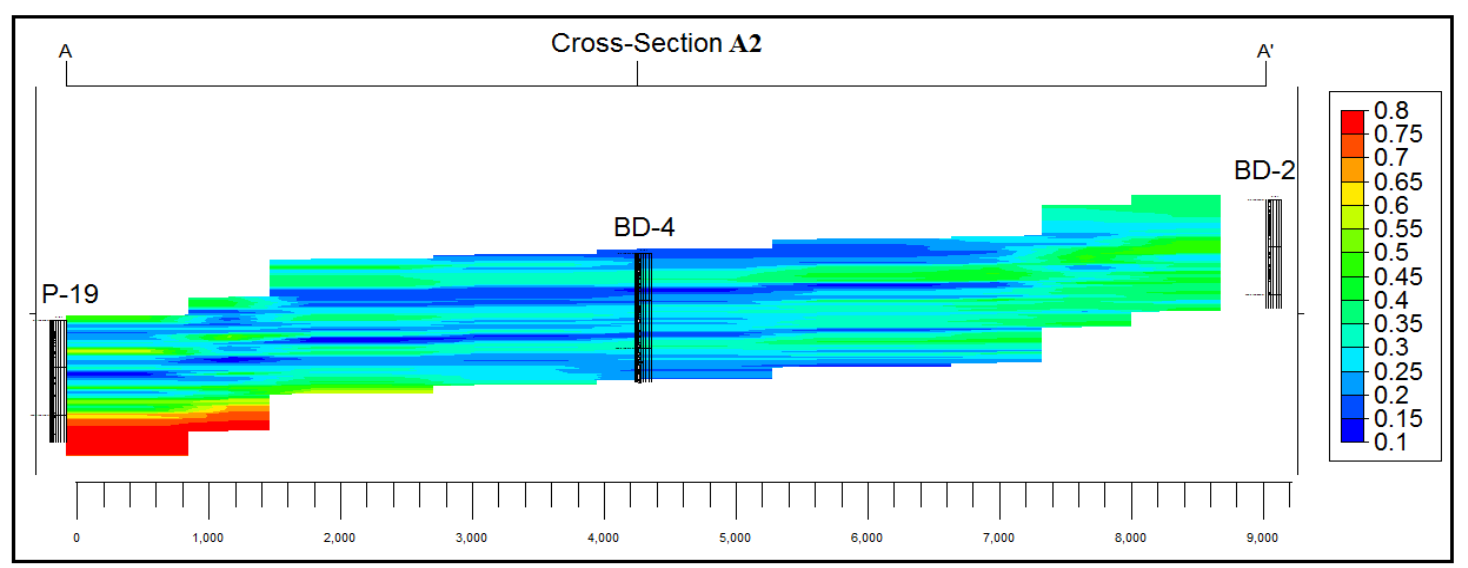

Fig. 10: Water saturation model of Mauddud Formation at section A2

\section{CONCLUSIONS}

1. The facies model of Mauddud Formation shows the dominance of open marine facies in the upper and middle parts of the formation, whereas mid-ramp facies occupies the lower part. The shoal facies represent approximately continuous or pinchoutunits among wells of study.

2. The petrophysical model shows high values of effective porosity towards higher structural depths, which are occupied by shoal and open marine facies. These facies are characterized by grain-supported texture, which makes them have good reservoir properties.

3. The water saturation increases at deep structural depths as observed in wells BD-1and P-19. In contrast, lower values occur upward the structure of Badra oil field. Therefore, the water saturation model indicates the structural control on the oil-water segmentation in Mauddud Formation.

\section{REFERENCES}

Bellen, R.C., van, H.V., Dunnington, R.W., and Morton, D.M., 1959. Lexique Stratigraphy. International. Asia, fasc., (3)10a, Iraq, 333pp.

Bellorini, J.P., Casas, J., Gilly, P., Jannes, P., and Matthews, P., 2003. Definition of a 3D Integrated Geological Model in a Complex and Extensive Heavy Oil Field, Oficina Formation, Faja de Orinoco, Venezuela Sincor OPCO, Caracas, Venezuela.

Cannon, 2018. Reservoir Modeling: A practical guide. Wiley Blackwell, 312 pp.

Cross, N., Goodall, I., Hollis, C., Burchette, T., Al-Ajmi, H.Z., Johnson, I.G., Mukherjee, R., Simmons, M., and Davies, R., 2010. Reservoir description of a mid-Cretaceous siliciclastic-carbonate ramp reservoir: Mauddud Formation in the Raudhatain and Sabiriyah fields, North Kuwait. Geo Arabia, 15(2):17-50.

Dunham, R.J., 1962.Classification of carbonate according to depositional texture, in Ham, W.E. (ed.), Classification of carbonate rocks. AAPG Memoir, 1:108-121.

Jassim, S.Z., and Goff, J.C., 2006. Geology of Iraq, Dolin, Prague and Moravian Museum, Brno, 337pp.

Pyrcz, M.J., and Deutsch, C.V., 2014. Geostatistical Reservoir Modeling, ${ }^{\text {nd }}$ Edition, Oxford University Press, New York, 448pp.

Sadooni, F.N., and Alsharhan, A.S., 2003. Stratigraphy, microfacies, and petroleum potential of the Mauddud Formation (Albian-Cenomanian) in the Arabian Gulf basin. The American Association of petroleum geologists bulletin, 87(10):1633-1680.

Schlumberger, 2010.Reservoir Engineering Course. Schlumberger, 137-177pp.

Turner, A.K., and Gable, C.W., 2008. A review of Geological Modelling. Colorado School of Mines, USA, Los Alamos National Laboratory, Los. 